\title{
Investigations of meltwater refreezing and density variations in the snowpack and firn within the percolation zone of the Greenland ice sheet
}

\author{
Victoria PARRY, ${ }^{1}$ Peter NIENOW, ${ }^{1}$ Douglas MAIR, ${ }^{2}$ Julian SCOTT, ${ }^{1,2}$ Bryn HUBBARD, ${ }^{3}$ \\ Konrad STEFFEN, ${ }^{4}$ Duncan WINGHAM ${ }^{5}$ \\ ${ }^{1}$ School of GeoSciences, University of Edinburgh, Drummond Street, Edinburgh EH8 9XP, UK \\ E-mail: v.l.parry@sms.ed.ac.uk \\ ${ }^{2}$ School of Geosciences, University of Aberdeen, Elphinstone Road, Aberdeen AB24 $3 U F$, UK \\ ${ }^{3}$ Centre for Glaciology, Institute of Geography and Earth Sciences, University of Wales, Aberystwyth SY23 3DB, UK \\ ${ }^{4}$ Cooperative Institute for Research in Environmental Sciences (CIRES), University of Colorado, Boulder, \\ CO 80309-0216, USA \\ ${ }^{5}$ Centre for Polar Observation and Modelling, University College London, Gower Street, London WC1E 6BT, UK
}

\begin{abstract}
The mass balance of polythermal ice masses is critically dependent on the proportion of surface-generated meltwater that subsequently refreezes in the snowpack and firn. In order to quantify this effect and to characterize its spatial variability, we measured near-surface $(<10 \mathrm{~m})$ snow and firn densities at an elevation of $\sim 1945 \mathrm{~m}$ a.s.l. in the percolation zone of the Greenland ice sheet in spring and autumn 2004. Results indicate that local snowpack depth above the previous end-of-summer 2003 melt surface increased by $\sim 5 \%(7.6 \mathrm{~cm})$ from spring to autumn while, over the same period, snowpack density increased by $>26 \%$, resulting in a $32 \%$ increase in net accumulation. This 'seasonal densification' increased at lower elevations, rising to $47 \% 10 \mathrm{~km}$ closer to the ice-sheet margin at $1860 \mathrm{~m}$ a.s.l. Density/depth profiles from nine sites within $1 \mathrm{~km}^{2}$ at $\sim 1945 \mathrm{~m}$ a.s.l. reveal complex stratigraphies that change over short spatial scales and seasonally. We conclude that estimates of massbalance change cannot be calculated solely from observed changes in surface elevation, but that nearsurface densification must also be considered. However, predicting spatial and temporal variations in densification may not be straightforward. Further, the development of complex firn-density profiles both masks discernible annual layers in the near-surface firn and ice stratigraphy and is likely to introduce error into radar-derived estimates of surface elevation.
\end{abstract}

\section{INTRODUCTION}

The future stability of the Greenland ice sheet is of fundamental importance to society: it is the biggest store of fresh water in the Northern Hemisphere, and any changes in mass balance will affect global sea levels and may influence the strength of the ocean thermohaline circulation (Rahmstorf and Ganopolski, 1999) and involve further Arctic climate feedbacks (Fichefet and others, 2003). Further, it is well recognized that predicted global warming is likely to be greater in high latitudes, with warming over Greenland estimated to be up to three times the global average (Intergovernmental Panel on Climate Change, http://www. grida.no/climate/ipcc_tar/wgl/index.htm). Since current temperatures are already causing significant melting, particularly around the southerly margins of the Greenland ice sheet (Steffen and others, 2004), future warming is likely to have an even greater effect on ice dynamics, surface melting and runoff. However, estimates of runoff from the ice sheet are currently limited by inadequate characterization of the extent of meltwater refreezing and superimposed ice formation (Pfeffer and others, 1991).

While estimates of meltwater production from ice in the ablation zone are relatively well predicted by positivedegree-day models (Braithwaite and Olesen, 1989), estimates of net runoff from the accumulation zone are very poor (Pfeffer and others, 1991). The upper boundary of effective melt is known as the 'runoff limit'; above this altitude, any meltwater produced during the summer subsequently refreezes in the snowpack/firn. However, while the position of the runoff limit corresponds approximately to the boundary of the percolation/wet-snow facies identified by Benson (1962), the actual position of the runoff limit remains a 'source of substantial uncertainty' (Pfeffer and others, 1991). Furthermore, the proportion of meltwater that actually runs off rather than refreezes in the wet snow zone is also highly uncertain. These uncertainties compromise estimates of current and future runoff from the Greenland ice sheet.

The European Space Agency's (ESA) CryoSat mission, due for relaunch in 2009, is set to observe the polar regions through satellite radar altimetry. Two of the key objectives of the mission are (1) to measure elevation changes over landbased ice masses, and (2) to interpret these changes in terms of mass loss or gain, thus improving our understanding of the response of the Earth's ice masses, and in particular the Greenland and Antarctic ice sheets, to climate change. Unfortunately, achieving these two objectives is especially difficult in the percolation zone of ice masses, as described in turn below.

1. Measurements of elevation change from satellite radar altimeters depend on accurate identification of radar reflections from the surface of the ice mass. However, the shape of the radar return wave is affected by reflections from internal structure of the near-surface snow and firn, 


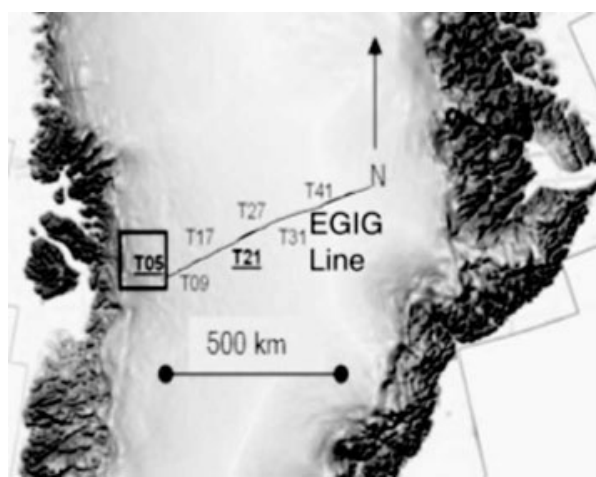

Fig. 1. The location of the field site, T05, on the EGIG line in Greenland.

termed volume backscatter (Ridley and Partington, 1988; Davis and Moore, 1993). Summer melting and refreezing within the percolation zone of ice masses may create ice layers, lenses and pipes within the near-surface snow and firn that can result in intense volume backscatter (Thomas and others, 2001), thereby generating ambiguous surface returns. Thus, temporal changes in the shape of the radar echo can result from seasonal variations in near-surface snow and firn density (Jezek and others, 1994; Scott and others, 2006b). Determining spatial variability in the extent of the seasonal metamorphism of the near-surface stratigraphy caused by summer melting and refreezing is therefore an important component of efforts to discriminate between surface and volume radar returns. Thus, there is a need to isolate the factors that determine the shape of the echo return in order to reduce measured elevation errors for satellite applications.

Pfeffer and Humphrey (1998) investigated ice-layer formation along a $40 \mathrm{~km}$ transect in the percolation zone of the Greenland ice sheet, and found that ice layers were more frequent at higher, colder sites, where infiltration was more limited, than at the lower, warmer sites. This suggests that volume backscatter will not automatically scale with increasing summer melt rate (and thus decreasing elevation) within the percolation zone. In addition, as well as ice-layer frequency, the precise position of ice layers within the snowpack is crucial to radar estimates of surface elevation since the nearer to the upper surface of the snowpack the ice layers form, the smaller the likely disparity between actual elevation and radar-derived elevation. However, predicting the precise location of a given ice layer may not be straightforward since it is governed by many factors, including local energy-balance conditions, driving melt and freezing processes, and the presence of hydraulic barriers inducing ponding of downward-percolating meltwaters (Wankiewicz, 1979; Pfeffer and others, 1990). Pfeffer and Humphrey (1996), in a further study of ice-layer formation in the percolation zone of the Tasersiaq ice cap, West Greenland, found the presence of fine-to-coarse grain stratigraphic boundaries provided a critical hydraulic barrier preventing downward percolation of meltwater and promoting the development of ice layers. Thus, overall snowpack stratigraphy, and spatial and temporal changes in its structure, will affect the contemporaneous and subsequent development of ice layers.
2. Interpreting changes in surface elevation in terms of change in mass is also complicated by surface melting and refreezing. In the most commonly anticipated scenario, surface melt, percolation and refreezing will cause a decrease in elevation but with no actual mass loss. In this case, the lost surface snow has been redistributed as ice layers in the near-surface layer whose bulk density has correspondingly increased (Braithwaite and others, 1994). Similarly, elevation may also remain constant between two periods even though mass has increased due to the addition of rain or solid summer precipitation which has subsequently melted and percolated into the underlying snowpack before refreezing (again thereby increasing snowpack density but not surface elevation). Thus, accurate assessment of mass balance may be masked by refreezing processes whose remaining signature is a near-surface density change rather than a surface elevation change. Unfortunately, determining the influence of summer densification on accurate geodetic measurements of mass balance is currently severely limited in the percolation zone of ice sheets by inadequate characterization of the extent, intensity and processes of meltwater refreezing (Pfeffer and others, 1991).

In this paper, we present field data from the percolation zone of the Greenland ice sheet in order to

1. Quantify the effect of the seasonal densification of nearsurface snow and firn on annual mass balance, and

2. Determine the seasonal and spatial changes in nearsurface stratigraphy caused by the processes of summer melting, percolation and refreezing.

\section{FIELD SITES AND METHODS}

Fieldwork was undertaken at $\sim 1945$ m elevation in the percolation zone of the Greenland ice sheet in the region of T05 $\left(69^{\circ} 51^{\prime} \mathrm{N}, 47^{\circ} 15^{\prime} \mathrm{W}\right)$ on the EGIG (Expéditions Glaciologiques Internationales au Groenland) line (Fig. 1). In order to investigate variability in near-surface density and stratigraphy over a range of spatial scales from $10^{0}$ to $10^{3} \mathrm{~m}$, snowpit and neutron-probe ( $\mathrm{N}$-probe) measurements were made at nine sites within $1 \mathrm{~km}$ of T05. Specifically, measurements were taken at T05, and then at $1 \mathrm{~m}, 10 \mathrm{~m}, 100 \mathrm{~m}$ and $1 \mathrm{~km}$ intervals along two transects from T05: transect $\mathrm{E}$, aligned in an east-northeasterly direction along the EGIG line towards the centre of the ice sheet (measurement locations E1-E4); and transect $\mathrm{S}$, aligned in a south-southeasterly direction perpendicular to the EGIG line (measurement locations S1-S4) (Fig. 2). Additional measurements were made $10 \mathrm{~km}$ from T05 along the EGIG line towards the centre of the ice sheet at T06 (2020 m elevation) and towards the edge of the ice sheet at T04 (1860 m elevation) (Fig. 2).

To determine the character of, and seasonal change in, the near-surface stratigraphy, measurements at each location were carried out during both spring (19 April-13 May) and autumn (28 August-21 September) of 2004. The spring data characterize the snow/firn before the summer melt, and the autumn data characterize the metamorphosed snow/ firn following summer melt, percolation and refreezing processes. At each of the 11 sites (Fig. 2), the following measurements were made. 


\section{Snow pits}

In spring 2004, snow pits were dug at each site down to the surface layer demarcating the end of the 2003 summer. This layer was easily identified as a hard, icy and continuous layer located beneath the autumn hoar, and was used as a reference surface for the bottom of all snow pits. Once this layer was identified in spring, ablation stakes were emplaced and used as markers to ensure this same horizon was used as a common reference for any depth change identified upon remeasurement in the autumn.

Standard snow-pit stratigraphic procedures were followed (Colbeck and others, 1990). The vertical pit face was 'cleaned' with a plastic brush to aid visual determination of the stratigraphic layers. The stratigraphic recognition of all individual layers was determined using a semiquantitative assessment of hardness (fist, finger, pencil or knife) carried out at $10 \mathrm{~mm}$ intervals down each profile. Once identified, each layer's thickness, grain size and crystal type were logged. Density measurements were taken from each layer using one of three tubes of differing diameter. The largest tube that could be pushed into an individual stratigraphic layer was used to extract a known volume of snow $\left(57,161\right.$ or $\left.227 \mathrm{~cm}^{3}\right)$ which was then weighed using a Newton balance to obtain density. Repeat measurements from stratigraphic layers were taken and averaged, and variability was found to be $2-3 \%$ for the large and medium-sized tubes, and $17 \%$ for the small tube. Ice layers, lenses and pipes were also recorded in the stratigraphy. These ice features were allocated a density of $0.8 \mathrm{~g} \mathrm{~cm}^{-3}$ since it was not possible to measure their density directly in the field and the ice was often observed to contain bubbles.

\section{Neutron-probe density profiling}

Density profiles were also measured at each site using an $\mathrm{N}$-probe (Morris and Cooper, 2003). The N-probe has a source of fast neutrons which lose energy by scattering when they interact with hydrogen atoms in the snow or ice. The density of the snow or ice is related to the number of slow neutrons returning to the probe detector (Morris and Cooper, 2003). Boreholes of $\sim 50 \mathrm{~mm}$ diameter were augered to depths of 6-10 m, and the $\mathrm{N}$-probe was lowered manually to the bottom of the borehole. The $\mathrm{N}$-probe was raised to the surface at the slowest possible speed $\left(\sim 50 \mathrm{~mm} \mathrm{~min}^{-1}\right.$, selected to maximize vertical resolution) by an electric winch, and the winch and data retrieval were controlled by a GeoVista Platform Logger and laptop computer located at the surface. The $\mathrm{N}$-probe logged the slow neutron count rate as a function of depth below surface at $10 \mathrm{~mm}$ intervals. The depth/count-rate profile was subsequently converted to a density profile using calibration equations (Morris and Cooper, 2003) to produce records of bulk density as a function of depth.

\section{Firn-core measurements}

At T04, the autumn snowpack was extremely hard, preventing insertion of the plastic density tubes. Density measurements were therefore taken from a shallow core extracted using a 'Kovacs' corer (diameter $70 \mathrm{~mm}$ ) adjacent to the autumn snow pit. The core was cut into stratigraphic layers identified visually, and the length and width of each cylindrical section were measured and weighed on a triplebeam balance to calculate density. The end-of-summer 2003

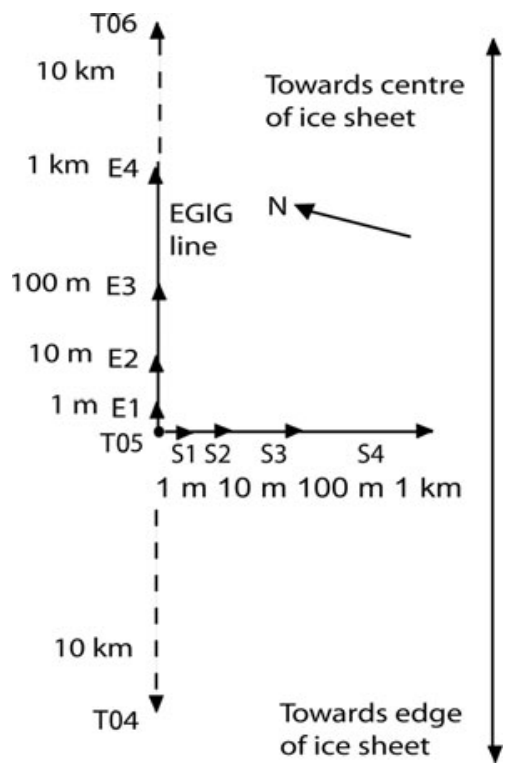

Fig. 2. A schematic map of the measurement locations.

layer had been identified from the snow pit in spring 2004, and, using an ablation stake, the core depth corresponding to accumulation during 2004 was known.

A $17 \mathrm{~m}$ long firn core was retrieved in spring 2004 from the bottom of the snow pit at E3 (Fig. 2) to obtain a longer time series of density measurements. This was shipped back to the UK where the core was cut into $0.1 \mathrm{~m}$ long cylindrical sections in a cold room at $-20^{\circ} \mathrm{C}$. Core section dimensions were measured using a caliper, and their mass was measured using an electric balance $( \pm 0.01 \mathrm{~g})$.

\section{RESULTS}

\section{Snowpack depth, density and accumulation}

The mean snowpack depth at the nine sites located within $1 \mathrm{~km}$ of T05 was $143.2 \mathrm{~cm}$ (standard deviation (s.d.) $4.0 \mathrm{~cm}$ ) in spring and $150.8 \mathrm{~cm}$ (s.d. 11.7) in autumn, yielding a mean summer increase in pit depth of $5.3 \%$ (Fig. 3a). The average density of the snowpack increased at all snow pits between spring and autumn (Fig. 3b). The mean snowpack density of all sites was $0.42 \mathrm{~g} \mathrm{~cm}^{-3}$ (s.d. 0.02) in spring and $0.53 \mathrm{~g} \mathrm{~cm}^{-3}$ (s.d. 0.04) in autumn, yielding a mean summer increase in density of $26.2 \%$. The average snow-pit accumulation expressed as a depth of water equivalent (w.e.) therefore increased from $60.5 \mathrm{~cm}$ (s.d. 3.4) in the spring to $79.6 \mathrm{~cm}$ (s.d. 5.5) in the autumn, an increase of $31.6 \%$ (Fig. 3c).

At T04 the depth to the end-of-summer 2003 layer was $112 \mathrm{~cm}$ in spring, and this increased by $4.5 \%$ to $117 \mathrm{~cm}$ in the autumn (Fig. 4a). Over the same time period the density increased by $47.4 \%$ from $0.38 \mathrm{~g} \mathrm{~cm}^{-3}$ to $0.56 \mathrm{~g} \mathrm{~cm}^{-3}$, resulting in a net increase in accumulation over the period of $55.5 \%$, rising from $42.0 \mathrm{~cm}$ w.e. in spring to $65.3 \mathrm{~cm}$ w.e. in autumn.

At T06, the depth to the end-of-summer 2003 layer increased from $130 \mathrm{~cm}$ in the spring to $141 \mathrm{~cm}$ in the autumn, an increase of $8.5 \%$ (Fig. $4 \mathrm{~b}$ ). The average pit density increased by $22.0 \%$ from $0.41 \mathrm{~g} \mathrm{~cm}^{-3}$ to $0.50 \mathrm{~g} \mathrm{~cm}^{-3}$, corresponding to a $33.5 \%$ increase in accumulation from $53.2 \mathrm{~cm}$ w.e. to $71.0 \mathrm{~cm}$ w.e. 

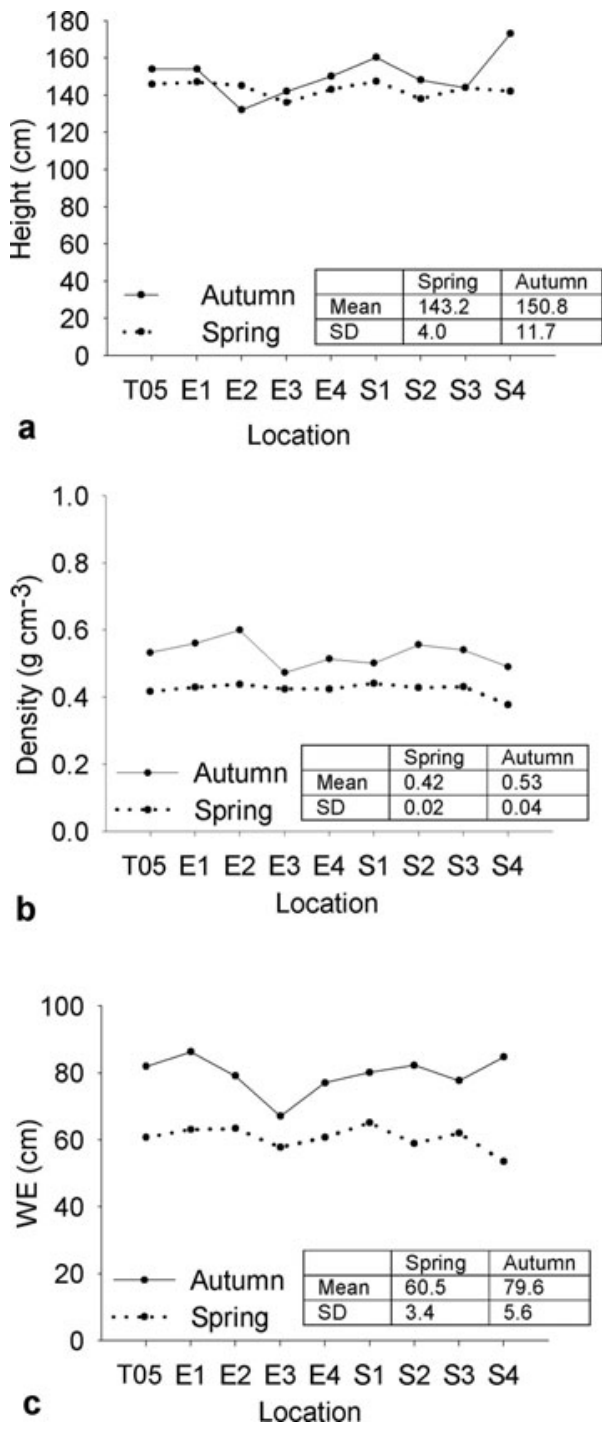

Fig. 3. Spring and autumn 2004 snow depth above the end-ofsummer 2003 surface (a), mean snowpack densities for spring and autumn 2004 (b) and accumulation (cmw.e.) between end-ofsummer 2003 surface layer and spring and autumn 2004 surfaces (c) for all snow pits within $1 \mathrm{~km}$ of T05.

\section{Temporal and spatial variability in density-depth profiles}

It is clear from Figure $3 \mathrm{~b}$ that there are distinct variations in mean density between the spring and autumn snowpacks. Plots of density with depth at individual snow pits demonstrate this seasonal variability in more detail. Density profiles for spring and autumn from three faces within a $1 \mathrm{~m}^{2}$ snow pit are plotted against each other for T05, E1 and S1 (Fig. 5). Figure 5 clearly shows that autumn densities are both generally higher and characterized by more extreme variations in density due to the presence of ice layers relative to the spring snowpack. This variability is replicated as the distance between snow pits increases up to length scales of $1 \mathrm{~km}$ (Fig. 6). However, density stratification is also locally highly variable, and spatially consistent ice layers are rarely present, even at length scales as short as $1 \mathrm{~m}$ (Figs 5 and 6).

Density profiles derived from the $\mathrm{N}$-probe at sites T05 and E1 are shown for spring and autumn 2004 (Fig. 7). It is clear from this record of bulk density that the $\mathrm{N}$-probe is detecting the seasonal densification in the snowpack above
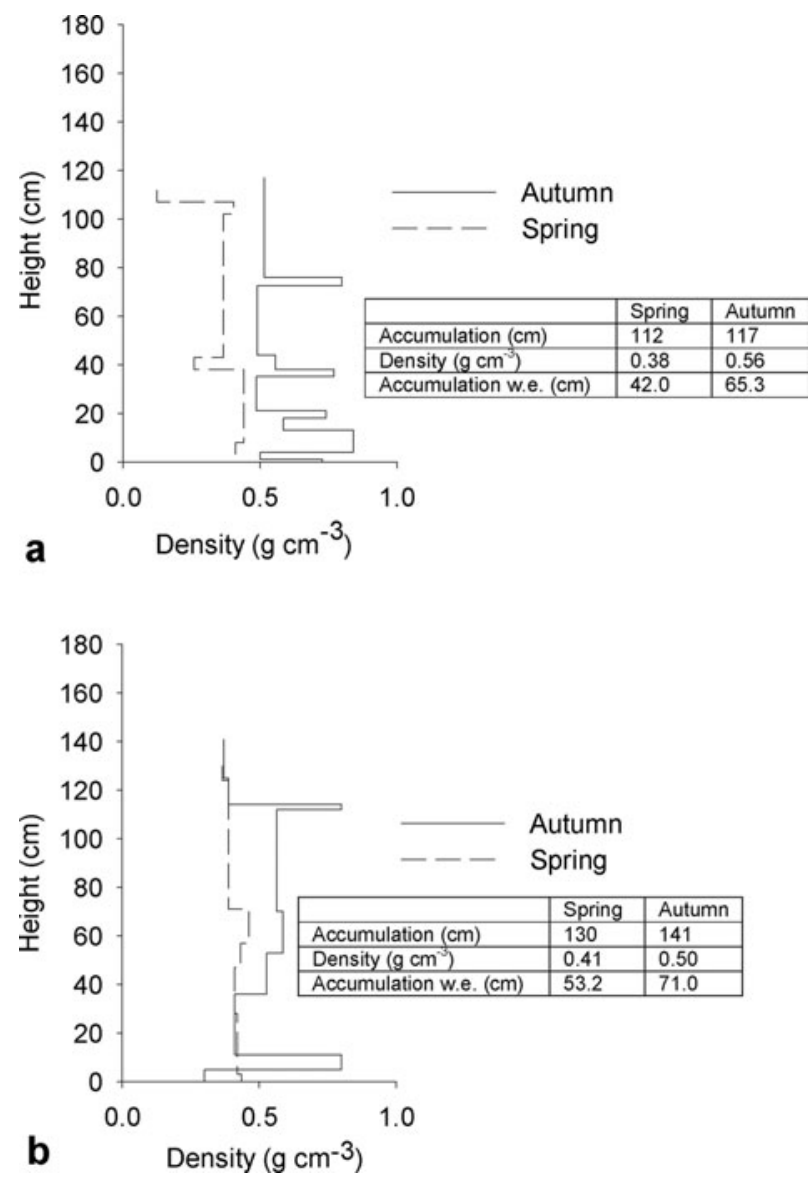

Fig. 4. Snowpack density profiles above the end-of-summer 2003 surface to spring and autumn 2004 surfaces at (a) T04 and (b) T06.

$\sim 1.5 \mathrm{~m}$ depth. However, it is also clear that, while density fluctuations are apparent throughout the N-probe record, there is no obvious annual signal which can be detected with any confidence. The density profile from the $17 \mathrm{~m}$ long core (Fig. 8) retrieved from E3 in autumn 2004 also shows substantial density variations. However, as with the N-probe profiles, the density changes cannot be obviously associated with an annual signal.

\section{Ice-layer concentration and location}

At the nine snow pits in the vicinity of T05 in autumn, the total number of ice layers in each pit of thickness $\geq 1 \mathrm{~cm}$ varies between one and six (mean $=3.1)$, while the combined ice thickness in each pit varies between 2.0 and $9.2 \mathrm{~cm}$ w.e. $($ mean $=6.1 \mathrm{~cm}$, s.d. $2.6 \mathrm{~cm})$. This accounts for $3.0-10.9 \%$ (mean $=7.5 \%$ ) of the total annual accumulation. Similar values are obtained from T06, where two ice layers totalled $6.4 \mathrm{~cm}$ w.e., representing $9.0 \%$ of the annual accumulation. In contrast, T04 is characterized by a substantially greater proportion of ice, yielding five ice layers (totalling $15.6 \mathrm{~cm}$ w.e.) which accounted for $23.9 \%$ of the annual accumulation. The distribution of ice layers in the autumn snowpack at the nine T05 sites does not reveal any clear depth of preferential formation, with layers being well distributed throughout the snowpack (Fig. 9). At T04 and T06, ice formation is concentrated at the base of the snowpack, with $75 \%$ of the ice present in the lowermost $10 \%$ of the snowpack at T06, and $82 \%$ of the ice present in the lowermost $30 \%$ at T04 (Fig. 9). However, it is clear from 


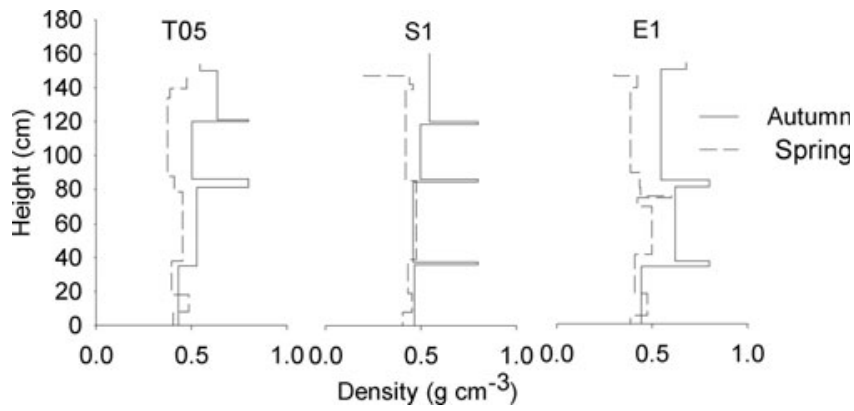

Fig. 5. Snowpack density profiles above the end-of-summer 2003 surface to spring and autumn 2004 surfaces at three locations within $1 \mathrm{~m}$ of each other: T05, E1 and S1.

the variability in ice distribution at the nine T05 sites (Fig. 9) that results from single pits at T05 and T06 may not be representative of those general areas. Thus, the available data do not suggest any obvious trend in the location of icelayer formation along the $20 \mathrm{~km}$ transect studied (Fig. 9). The locations of the 34 ice layers from all 11 snow pits are also not correlated with any particular stratigraphic boundary: $26 \%$ of layers are located on (downwards) fine-to-coarse snow grain transitions, $18 \%$ on (downwards) coarse-to-fine grain transitions, and the remaining $56 \%$ occur where there is no apparent change in grain size. However, transitions where there is no apparent change in grain size probably result from thin wind crusts which will not be visually obvious in the metamorphosed autumn snowpack.

\section{DISCUSSION}

Snowpack investigations in 2004 at nine sites within $1 \mathrm{~km}$ of T05 demonstrate that, while there was a $7.6 \mathrm{~cm}(5.3 \%)$ increase in average snowpack thickness between spring and autumn (Fig. 3a), there was a substantial $(26.2 \%)$ increase in mean snowpack density over the same period (Fig. 3b). Similar changes were observed at T06, located $10 \mathrm{~km}$ up-ice from T05, where snowpack thickness and density increased by $8.5 \%$ and $22.0 \%$ respectively. In contrast, observations $10 \mathrm{~km}$ down-ice at T04 revealed a $4.5 \%$ increase in snowpack thickness and a $47.4 \%$ increase in density. These density increases result primarily from surface melting, meltwater percolation and subsequent refreezing at depth

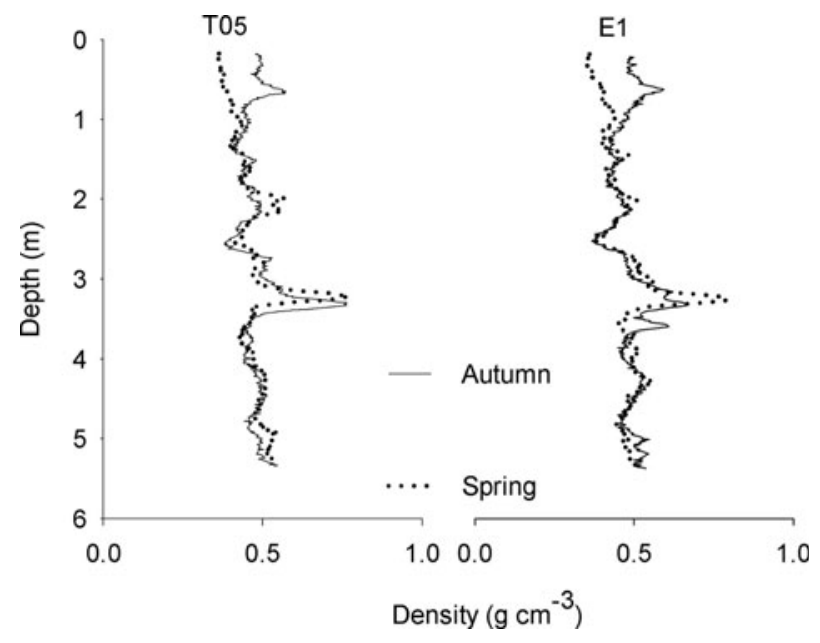

Fig. 7. N-probe density profiles at T05 and E1 in spring and autumn 2004.

within the surface snowpack. The fact that densities increased substantially without any decrease in snow depth results from additional mass inputs as summer precipitation in the form of snow or rain. In addition, snow compaction during warmer summer temperatures also contributes to increased densities. The more pronounced densification at T04 is an expected consequence of the higher melt rates at lower elevations (Braithwaite and others, 1994).

The consequence of the melt, percolation and refreezing processes is a complex end-of-summer snowpack containing numerous individual ice layers or lenses located at different depths (Figs 5, 6 and 9). These ice inclusions are rarely spatially continuous, even at short length scales of $<1 \mathrm{~m}$ (Fig. 5), contrasting with the findings of Pfeffer and Humphrey (1996) at the Tasersiaq ice cap where the overall pattern of stratigraphy was easily traceable from one pit to another. The difference between that study and ours likely reflects the complex stratigraphically controlled snowpack permeability (Wankiewicz, 1979) at T05, resulting from the presence of sastrugi and buried wind crusts in this zone of persistent katabatics (Steffen and Box, 2001). These wind crusts, which are often observable in the snow pits as $1-2 \mathrm{~mm}$ thick ice layers, act as hydraulic barriers to the downward percolation of meltwater. This effect is consistent, with almost one in five $(18 \%)$ of the ice layers in our study being

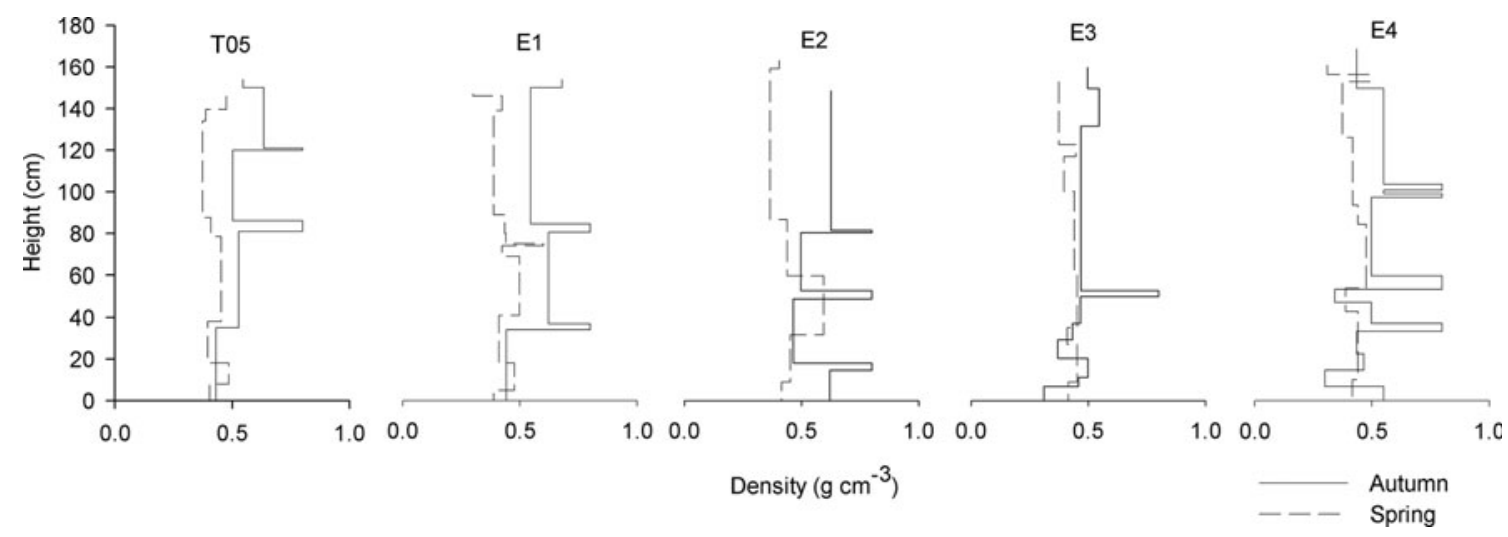

Fig. 6. Snowpack density profiles above the end-of-summer 2003 surface to spring and autumn 2004 surfaces at five locations along a $1 \mathrm{~km}$ transect: T05, E1, E2, E3 and E4. 


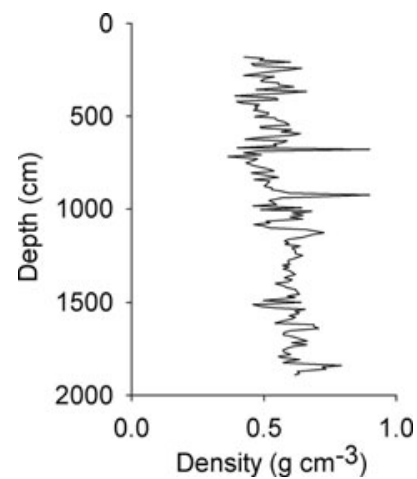

Fig. 8. Density profile of a firn core retrieved at E3 in spring 2004.

associated with coarse-to-fine grain boundaries, and 56\% of layers being unassociated with any visible transition, while ice layers in Pfeffer and Humphrey's (1996) study were overwhelmingly associated with (downward) fine-to-coarse grain boundaries.

While the ice layers identified in our study are rarely spatially continuous, their presence (and the overall increase in near-surface density they create) will result in very different radar echo returns between spring and autumn, with a resultant effect on radar 'estimates' of elevation (Jezek and others, 1994; Scott and others, 2006a). This impact will have a seasonal pattern because the end-of-summer layers are progressively buried during the winter by the lowerdensity winter snowpack. Work is currently ongoing to determine precisely how these seasonal changes will influence elevation estimates derived from radar altimeters. The considerable change in snowpack density between seasons (Fig. 3b) also ensures that, even if surface elevation changes only slightly (Fig. 3a), the actual mass change may be considerable. Thus, in areas such as the percolation zone, where the snowpack shows substantial seasonal changes in density, mass-balance estimates cannot be simply based on measured changes in surface elevation.

Our findings do not replicate those of Pfeffer and Humphrey (1998) who found an increase in the incidence of internal ice layers at colder sites located higher in the percolation zone. However, our $20 \mathrm{~km}$ long snow-pit transect, which showed no discernible pattern in ice-layer concentration and location, was only half the length of that investigated by Pfeffer and Humphrey (1998). It could well be that significant spatial changes in ice-layer prevalence and distribution may be identified upon extending our transect in future studies.

At T05, the average annual accumulation between end of summer 2003 and end of summer 2004 was $79.6 \mathrm{~cm}$ w.e., with $31.6 \%$ of this value accumulated in summer 2004. This mean accumulation is $22-115 \%$ higher than measurements in the vicinity of T05 from 27 of the years between 1950 and 1988 and $52 \%$ higher than the mean accumulation rate of $52.2 \mathrm{~cm}$ w.e. during these 27 years (Fig. 10a) (Benson, 1962; Seckel, 1977; Stober, 1986; Anklin and others, 1994). More recently, automated snow-depth measurements have been made within $3 \mathrm{~km}$ of T06 at Crawford Point $\left(69^{\circ} 52^{\prime} 47^{\prime \prime} \mathrm{N}\right.$, $\left.49^{\circ} 59^{\prime} 12^{\prime \prime} \mathrm{W}\right)$, a Greenland Climate Network (GC-Net) automatic weather station (AWS), at an elevation of $2022 \mathrm{~m}$ (Steffen and others, 1996; Steffen and Box, 2001). These data reveal that average annual accumulated snow/ firn in eight of the years between 1995 and 2004 is $1.09 \mathrm{~m}$

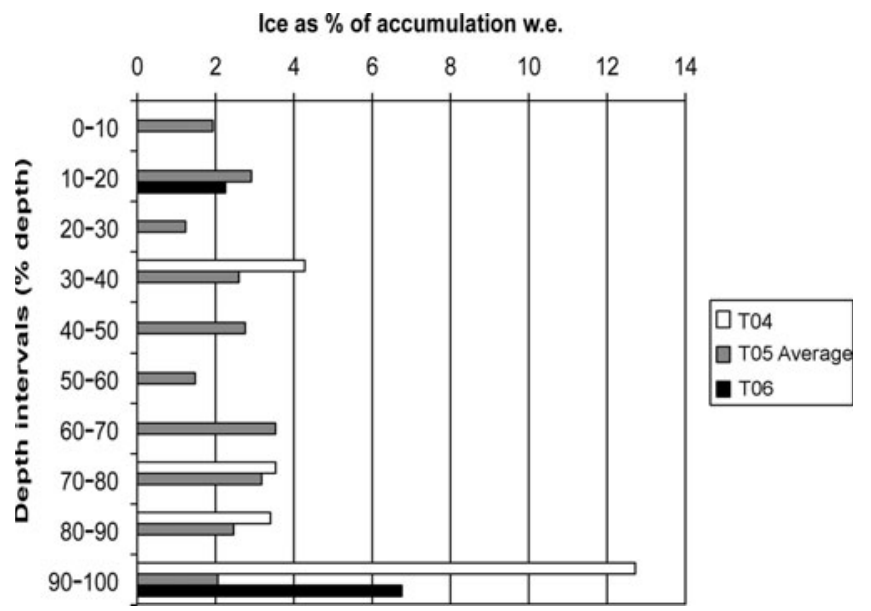

Fig. 9. The location of ice layers expressed as a percentage of accumulation within the snowpack at T04 and T06 and as an average percentage of accumulation at all nine snow pits within $1 \mathrm{~km}$ of T05.

and that the interannual variability in this rate is high (Fig. 10b), characterized by a coefficient of variation of $38 \%$. The annual (2003/04) accumulated snow depth of $1.41 \mathrm{~m}$ measured at T06 in the present study is considerably higher than the $1.06 \mathrm{~m}$ accumulation over the same period at Crawford Point. Thus, both the high interannual variability in accumulation measured at Crawford Point and the difference in accumulation between Crawford Point and T06 in 2003/04 emphasize that any single annual measurement of accumulation is inadequate for investigating rates of long-term change on the basis of comparisons with data from earlier years. Additional measurements of snow accumulation in the vicinity of T05 in 2004 using airborne radar and laser altimetry indicate that snow-depth distribution is bimodal, with accumulation on low-gradient plateaus (such as T05) averaging $0.2 \mathrm{~m}$ deeper than on more steeply sloping terrain (Helm and others, 2007). Thus, a longer time series is needed to provide better grounds for comparison between our 2004 observations and earlier historical records.

Efforts to obtain a longer time series in mass balance using a down-borehole N-probe to detect annual density variations proved unsuccessful (Fig. 7). This method has been used at higher elevations in the dry snow zone of the Greenland ice sheet to detect annual layers from cyclic changes in the density profile (Hawley and others, 2006). However, while distinct density fluctuations are apparent in the $\mathrm{N}$-probe record at T05, there is no obvious annual signal which can be detected with any confidence. This may reflect the way in which the $\mathrm{N}$-probe averages density, thereby losing detail at a resolution of centimetres to millimetres. However, it is also likely, that the complex patterns of melt and refreezing that are prevalent in the vicinity of T05 in the percolation zone preclude the use of density fluctuations for extending annual mass-balance time series. Density variations in the $17 \mathrm{~m}$ long firn core retrieved from site E3 (Fig. 2) in spring 2004 also appear incapable of resolving annual layers (Fig. 8). In order to extend the recent annual mass-balance record at T05, we are currently carrying out isotopic and ionic analysis, as used successfully by Fischer and others (1995) to resolve annual layers in the $17 \mathrm{~m}$ long core. 


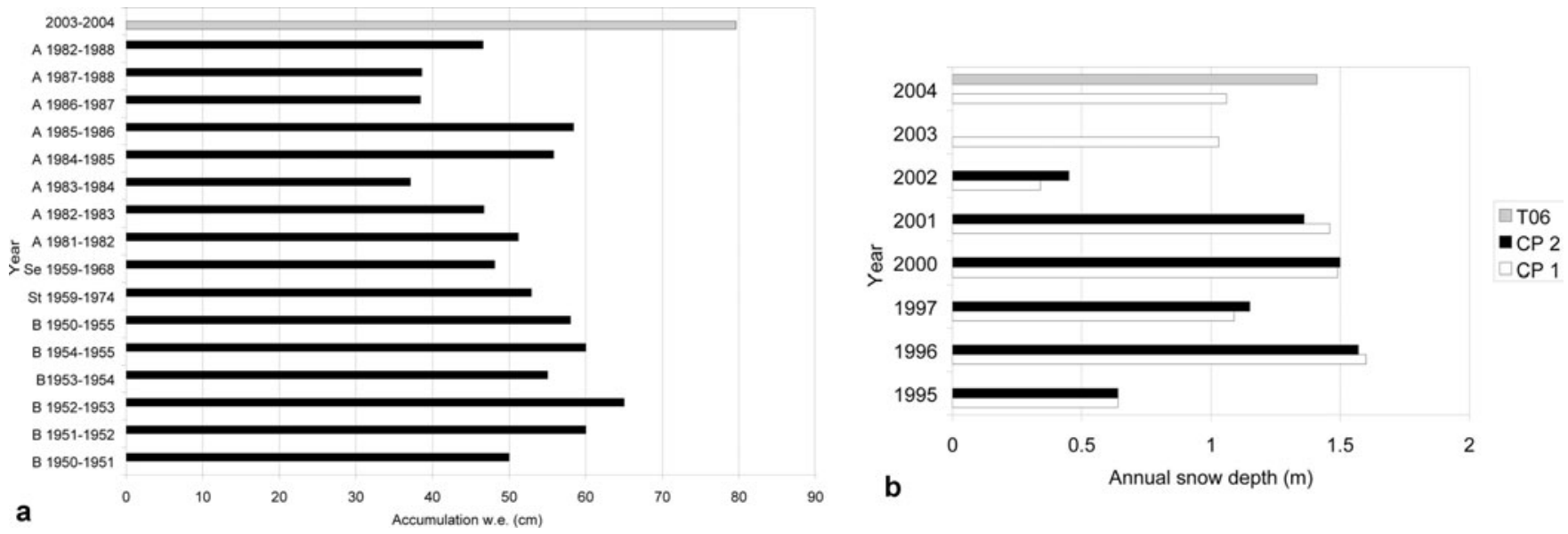

Fig. 10. (a) Previous accumulation rates (cm w.e.) measured at T05: annual and average 1950-55 (B 1950-55; Benson, 1962); average 195974 (St 1959-74; Stober, 1986); average 1959-68 (Se 1959-68; Seckel, 1977); annual and average 1982-88 (A 1982-88; Anklin and others, 1994); and end of summer 2003 to end of summer 2004 (2003-04; this study). (b) Annual snow accumulation at Crawford Point AWS (sensors 1 (CP1) and 2 (CP2)), and at nearby T06 (this study) from end-of-summer 2003 surface to end-of-summer 2004 surface.

\section{CONCLUSIONS}

Measurements of snowpack structure, made before and after summer melting, were carried out in the percolation zone of the Greenland ice sheet in spring and autumn 2004. These were made along two $1 \mathrm{~km}$ long transects from T05, as well as at single locations at T06 and T04, respectively located $10 \mathrm{~km}$ up-ice and down-ice from T05 along the EGIG line (Fig. 2).

Results show that small increases in snowpack depth were observed between spring and autumn 2004 within the percolation zone (increases of $4.5 \%, 5.3 \%$ and $8.5 \%$ at T04, T05 and T06 respectively). However, mean snowpack densities increased significantly over this period (increases of $47.4 \%, 26.2 \%$ and $22.0 \%$ at T04, T05 and T06 respectively) and included the creation of numerous ice layers (Figs 5, 6 and 9). Densification results from several processes, including: warming of the snowpack before the onset of melt; additional summer mass inputs in the form of solid and liquid precipitation; surface melting; meltwater percolation; subsequent refreezing at depth within the snowpack; and snow compaction during warmer summer temperatures. The more pronounced densification with decreasing elevation from T06 to T04 is an expected consequence of the higher melt rates at lower elevation (Braithwaite and others, 1994).

The considerable change in snowpack density between seasons (Fig. 3b) indicates that significant changes in mass can occur in this zone with only very limited changes in surface elevation. For example, at T05 the 5.3\% increase in snow depth reflected a $31.6 \%$ increase in net accumulation. Thus, in areas such as the percolation zone, where the snowpack shows substantial seasonal changes in density, mass-balance estimates should not be based solely on observed changes in surface elevation.

Density/depth profiles from nine sites within $1 \mathrm{~km}^{2}$ around T05 reveal that the snowpack in this region has a highly variable density stratigraphy, and that this stratigraphy changes over short temporal and spatial scales. Ice layers are rarely spatially continuous at length scales $>\sim 1 \mathrm{~m}$ (Figs 5 and 6), and this complexity may be partly responsible for prohibiting clear identification of annual layers in deeper core and $\mathrm{N}$-probe depth-density profiles. Ice layers and lenses formed within the near-surface snowpack contribute markedly to the overall increase in near-surface density, and these will result in very different radar echo returns between spring and autumn. Unless this seasonal effect is accounted for, it may contribute to ambiguous radar 'estimates' of surface elevation (Jezek and others, 1994; Scott and others, 2006a, b).

The depth of discontinuous ice layers in the autumn snowpack shows no systematic relationship with boundaries defined by grain-size change, as described by Pfeffer and Humphrey (1996). Instead, we believe the precise depths of ice inclusions in this area of the Greenland ice sheet may often be controlled by the formation and burial of sastrugi and wind crusts that are prevalent within the spring snowpack in this region. Also, we measured no discernible increase in internal ice layers at higher colder sites in the percolation zone, as reported by Pfeffer and Humphrey (1998), although a longer transect would be needed to test this hypothesis effectively.

\section{ACKNOWLEDGEMENTS}

This paper is a contribution to the validation of the ESA CryoSat. The work is funded by the UK Natural Environment Research Council through grant NER/O/S/2003/00620. Our thanks for assistance in the field go to V. Helm, S. Chastin and C. Bøggild, and for logistical support go to K. Keller, R. Forsberg, M. Davidson, R. Abbot and K. Bar Friis. We thank T. Pfeffer, an anonymous referee and the Associate Editor, R. Brown, for constructive and insightful reviews which greatly improved the paper.

\section{REFERENCES}

Anklin, M., B. Stauffer, K. Geis and D. Wagenbach. 1994. Pattern of annual snow accumulation along a West Greenland flow line: no significant change observed during recent decades. Tellus, 46B(4), 294-303.

Benson, C.S. 1962. Stratigraphic studies in the snow and firn of the Greenland ice sheet. SIPRE Res. Rep. 70.

Braithwaite, R.J. and O.B. Olesen. 1989. Calculation of glacier ablation from air temperature, West Greenland. In Oerlemans, J., ed. Glacier fluctuations and climatic change. Dordrecht, Kluwer Academic Publishers, 219-233. 
Braithwaite, R.J., M. Laternser and W.T. Pfeffer. 1994. Variations of near-surface firn density in the lower accumulation area of the Greenland ice sheet, Pâkitsoq, West Greenland. J. Glaciol., 40(136), 477-485.

Colbeck, S.C. and 7 others. 1990. The international classification for seasonal snow on the ground. Wallingford, Oxon., International Association of Scientific Hydrology. International Commission on Snow and Ice.

Davis, C.H. and R.K. Moore. 1993. A combined surface- and volume-scattering model for ice-sheet radar altimetry. J. Glaciol., 39(133), 675-686.

Fichefet, T., C. Poncin, H. Goosse, P. Huybrechts, I. Janssens and H. Le Treut. 2003. Implications of changes in freshwater flux from the Greenland Ice Sheet for the climate of the 21st century. Geophys. Res. Lett., 30(17), 1911. (10.1029/2003GL017826.)

Fischer, H., D. Wagenbach, M. Laternser and W. Haeberli. 1995. Glacio-meteorological and isotopic studies along the EGIG line, central Greenland. J. Glaciol., 41(139), 515-527.

Hawley, R., E. Morris, R. Cullen, U. Nixdorf, A. Shepherd and D. Wingham. 2006. ASIRAS airborne radar resolves internal annual layers in the dry-snow zone of Greenland. Geophys. Res. Lett., 33(4), L04502. (10.1029/2005GL025147.)

Helm, V. and 6 others. 2007. Winter accumulation in the percolation zone of Greenland measured by airborne radar altimeter. Geophys. Res. Lett., 34(6), L06501. (10.1029/2006GL029185.)

Jezek, K.C., P. Gogineni and M. Shanableh. 1994. Radar measurements of melt zones on the Greenland ice sheet. Geophys. Res. Lett., 21(1), 33-36.

Morris, E.M. and J.D. Cooper. 2003. Density measurements in ice boreholes using neutron scattering. J. Glaciol., 49(167), 599-604.

Pfeffer, W.T. and N.F. Humphrey. 1996. Determination of timing and location of water movement and ice-layer formation by temperature measurements in sub-freezing snow. J. Glaciol., 42(141), 292-304.

Pfeffer, W.T. and N.F. Humphrey. 1998. Formation of ice layers by infiltration and refreezing of meltwater. Ann. Glaciol., 26, 83-91.

Pfeffer, W.T., T.H. Illangasekare and M.F. Meier. 1990. Analysis and modeling of melt-water refreezing in dry snow. J. Glaciol., 36(123), 238-246.
Pfeffer, W.T., M.F. Meier and T.H. Illangasekare. 1991. Retention of Greenland runoff by refreezing: implications for projected future sea level change. J. Geophys. Res., 96(C12), 22,117-22,124.

Rahmstorf, S. and A. Ganopolski. 1999. Long-term global warming scenarios computed with an efficient coupled climate model. Climatic Change, 43(2), 353-367.

Ridley, J. and K. Partington. 1988. A model of satellite radar altimeter return from ice sheets. Int. J. Remote Sens., 9(4), 601-624.

Scott, J., D. Mair, P. Nienow, V. Parry and E. Morris. 2006a. A ground-based radar backscatter investigation in the percolation zone of the Greenland Ice Sheet. Remote Sens. Environ., 104, 361-373.

Scott, J., P. Nienow, V. Parry, D. Mair, E. Morris and D. Wingham. 2006b. The importance of seasonal and annual layers in controlling backscattter to radar altimeters across the percolation zone of an ice sheet. Geophys. Res. Lett., 33(24), L24502. (10.1029/2006GL027974.)

Seckel, H. 1977. Höhenänderungen im grönländischen Inlandeis zwischen 1959 und 1968. Medd. Grønl., 187(4), 192-200.

Steffen, K. and J. Box. 2001. Surface climatology of the Greenland ice sheet: Greenland Climate Network 1995-1999. J. Geophys. Res., 106(D24), 33,951-33,964.

Steffen, K., J. Box and W. Abdalati. 1996. Greenland Climate Network: GC-Net. CRREL Spec. Rep. 96-27, 98-103.

Steffen, K., S. Nghiem, R. Huff and G. Neumann. 2004. The melt anomaly of 2002 on the Greenland Ice Sheet from active and passive microwave satellite observations. Geophys. Res. Lett., 31(20), L20402. (10.1029/2004GL020444.)

Stober, M. 1986. Die deutschen geodatischen arbeiten in Rahmen der internationalen glaziologischen Gronland Expeditions (EGIG) 1959-1974. Deut. Geod. Komm. Publ. B281.

Thomas, R. and 7 others. 2001. Mass balance of higher-elevation parts of the Greenland ice sheet. J. Geophys. Res., 106(D24), $33,707-33,716$.

Wankiewicz, A. 1979. A review of water movement in snow. In Colbeck, S.C. and M. Ray, eds. Modeling of Snow Cover Runoff, 26-28 September 1978, Hanover, New Hampshire. Proceedings. Hanover, NH, U.S. Army Corps of Engineers. Cold Regions Research and Engineering Laboratory, 222-252. 